\title{
Growth, tolerance to low salinity, and osmoregulation in decapod crustacean larvae
}

\author{
Gabriela Torres ${ }^{1,2, *}$, Luis Giménez ${ }^{1}$, Klaus Anger ${ }^{2}$ \\ ${ }^{1}$ School of Ocean Sciences, Bangor University, Menai Bridge, LL59 5AB, UK \\ ${ }^{2}$ Biologische Anstalt Helgoland, Foundation Alfred Wegener Institute for Polar and Marine Research, 27498 Helgoland, Germany
}

\begin{abstract}
Marine invertebrate larvae suffer high mortality due to abiotic and biotic stress. In planktotrophic larvae, mortality may be minimised if growth rates are maximised. In estuaries and coastal habitats however, larval growth may be limited by salinity stress, which is a key factor selecting for particular physiological adaptations such as osmoregulation. These mechanisms may be energetically costly, leading to reductions in growth. Alternatively, the metabolic costs of osmoregulation may be offset by the capacity maintaining high growth at low salinities. Here we attempted identify general response patterns in larval growth at reduced salinities by comparing 12 species of decapod crustaceans with differing levels of tolerance to low salinity and differing osmoregulatory capability, from osmoconformers to strong osmoregulators. Larvae possessing tolerance to a wider range in salinity were only weakly affected by low salinity levels. Larvae with a narrower tolerance range, by contrast, generally showed reductions in growth at low salinity. The negative effect of low salinity on growth decreased with increasing osmoregulatory capacity. Therefore, the ability to osmoregulate allows for stable growth. In euryhaline larval decapods, the capacity to maintain high growth rates in physically variable environments such as estuaries appears thus to be largely unaffected by the energetic costs of osmoregulation.
\end{abstract}

KEY WORDS: Biomass growth · Crustacean larvae - Physiological plasticity · Osmoregulation • Osmotic stress $\cdot$ Salinity

\section{INTRODUCTION}

Salinity is a key ecological factor influencing the patterns of growth and distribution in marine organisms (Kinne 1971, Anger 2003). While stenohaline marine species live and develop under stable oceanographic conditions with high salt concentrations, the benthic juvenile and adult life-history stages of some euryhaline species also occupy estuarine areas, being physiologically well adapted to strong variations in salinity. The key adaptations to osmotic stress comprise reductions of integumental permeability (Rainbow \& Black 2001) and, more importantly, strong capabilities of intra- and extracellular osmo- and ion regulation (Péqueux 1995, Freire et al. 2003, Augusto et al. 2009, Charmantier et al. 2009). The more physiologically vulnerable larval stages of coastal marine organisms may experience osmotic stress, irrespective of the habitat occupied by the conspecific adults. Since most coastal marine and estuarine animals develop through a larval phase, osmotic stress is a common problem for their early life-history stages (Anger 2001). Larvae are small (mostly $<1 \mathrm{~mm}$ size), slowly swimming planktonic organisms, which are unable to overcome the current speeds in their natural pelagic environment. Consequently, they are largely unable to perform escape responses other than passively sinking to bottom layers, where they may resume swimming. Osmotic stress may therefore affect larval survival and growth, and this selection pressure has favoured the evolution of particular life-history strategies and physiological adaptations in early developmental stages.

As an adaptive response to unfavourable conditions prevailing in the habitat of the adults, most estuarine 
species follow a strategy of larval export towards the sea (Strathmann 1982). In many of these species, the females show reproductive migrations to the ocean, so that the physiologically sensitive larvae hatch in seawater (e.g. Callinectes sapidus: Tankersley et al. 2002). In other exporting species, however, the larvae are directly released in brackish or freshwater, where the adults live, and are subsequently transported by surface currents towards lower estuarine or coastal marine waters with higher and less variable salinities (e.g. Armases roberti: Anger et al. 2006, Torres et al. 2006; Neohelice granulata: Anger et al. 2008a). In both cases, the late larval or early juvenile stages begin to actively reimmigrate into estuarine habitats (see e.g. Luppi et al. 2002, Ogburn et al. 2007), where they are exposed to increasingly stressful hypo-osmotic conditions.

Only relatively few brackish- and freshwater-inhabiting species show a retention strategy and, therefore, must have euryhaline larvae, which can develop in estuarine or even in landlocked habitats with low or unpredictable salinities (e.g. Armases miersii: Anger 1995; Anger et al. 2008b; Rhithropanopeus harrisii: Chen et al. 1997; Crangon crangon: Paula 1998). Independent of life-history strategies, the larvae of most estuarine species are thus exposed to conditions of osmotic stress at least during some developmental period.

During the extended period of planktonic development, the larvae of fully marine species may be transported to regions of estuarine influence, where they may be temporarily exposed to reduced salinities (Jury et al. 1994). Physiological consequences of salinity changes in surface waters can be mitigated by vertical migrations (Queiroga \& Blanton 2004); however, the benefit of this behavioural avoidance response may be offset by nutritional stress in deeper water layers (Giménez \& Anger 2005). Short-term fluctuations in salinity should thus, directly or indirectly, affect the chances for successful planktonic larval development in decapod crustaceans and other invertebrates (Richmond \& Woodin 1996, Anger 2003).

Studies on the effects of salinity on larval survival and development in marine and estuarine decapod crustaceans are abundant in the literature (reviewed in Anger 2003). In recent years, studies on the ontogeny of osmoregulation have revealed the presence of physiological adaptations to osmotic stress in early life history stages of several species (Charmantier 1998). In some species, both osmoconforming and osmoregulating larval stages have been identified in laboratory experiments, apparently related to changing ecological conditions during ontogenetic migrations in the natural environment (Charmantier et al. 2002, Cieluch et al. 2007, Anger et al. 2008b).

Little information is available on how osmotic stress affects larval growth, biomass and chemical composi- tion, and on whether osmoregulatory adaptations are sufficient to buffer the potentially negative effects of low salinity. Reduced rates of feeding, assimilation and growth have been observed, when decapod larvae are exposed to osmotic stress (Johns 1982, Anger et al. 1998). Torres et al. (2002) found that the negative effects of reduced salinity on first-stage larval growth were stronger in stenohaline than in euryhaline species (Cancer pagurus, Homarus gammarus vs. Carcinus maenas, Neohelice granulata). In another study (Torres et al. 2007a), differential effects on biomass and growth of the larval stages of euryhaline crabs (Armases spp.) suggested that the capability of osmoregulation mitigates the effects of reduced salinity.

In the present paper, we compare the available information on salinity effects on larval growth in 7 species of decapod crustaceans (Torres et al. 2002, 2007a) with new data obtained from 5 other species, covering a wider range of salinity tolerance than in previous studies, to identify general response patterns in the growth of decapod larvae exposed to hypo-osmotic stress. The species and stages selected for this paper enabled us to assess, for the first time, short-term responses of decapod crustacean larvae to osmotic stress in terms of growth. In particular, we evaluated (1) relationships between the degree of tolerance to low salinity (measured in terms of larval survival) and growth; and (2) relationships between larval growth at moderately low salinities and osmoregulatory capacity (known from previous studies listed in Table 1). Here we test 2 working hypotheses: (1) stenohaline species will show decreasing growth at reduced salinities, while euryhaline species (i.e. those surviving in a wider range of salinities) should maintain high growth rates in a broader range of salinities; and (2) the capability to hyper-osmoregulate will buffer negative effects of hypo-osmotic stress on growth rates; as an alternative outcome, osmoregulation may stabilize the rate of larval survival. However, the buffering effect on growth might be offset by the energy demand for this active physiological process. Growth was measured in terms of changes in dry mass, protein and lipid content, which are good descriptors of the level of energy reserves and larval biomass in decapod crustaceans (Torres et al. 2007a).

\section{MATERIALS AND METHODS}

In order to test our hypotheses, we compared previously published data on larval growth in 7 species (Torres et al. 2002, 2007a) with new experimental data obtained for 5 additional species, thereby covering a wider range of interspecific and ontogenetic variation in the range of tolerance of low salinity and osmoregu- 
latory capacity (for brief characterization of species and references, see Table 1). Our data thus comprise values of larval biomass (dry mass, DW; protein; lipid) in 12 species, and osmoregulatory capacity in 7 species obtained from laboratory experiments conducted under similar conditions of photoperiod, temperature and salinity.

Experiments. Set-up: To avoid potentially confounding effects of genetic variability or differential acclimation, we used only larvae from the same population for each species. All experiments consisted of exposing several groups of larvae (5 replicates) of a particular stage to different salinity conditions. The exposure time corresponded to $50 \%$ of the moult cycle (ca. 2 d) for all stages and species tested (see Torres et al. 2002, 2007 a for details of experiments). The salinity ranges chosen represent environmental conditions likely to occur in each species' habitat. The salinity range to which larvae of marine species were exposed was narrow (20 to $32 \%$ ). The same range was also used for the zoea I stage of a marine population of Carcinus maenas (originating from Helgoland, North Sea, where this species is only a weak hyper-osmoregulator; Cieluch et al. 2004). By contrast, the salinity range for coastal or estuarine species varied between 5 and $32 \%$, and 15 and $32 \%$, depending on larval salinity tolerance in each species.

Larval 'tolerance' of low salinity was defined as survival at conditions ranging between the minimum salinity tolerated by a given instar of a given species and the fixed maximum (32\%). The minimum salinity tolerated by a species was operatively defined by the minimum salinity $\left(S_{\mathrm{m}}\right)$ for which the percentage survival was $\geq 80 \%$ throughout a given stage (i.e. exposure to $S_{\mathrm{m}}$ for 2 to $5 \mathrm{~d}$ depending on stage and species). This high threshold value avoids a possible bias in biomass estimation as a consequence of differential mortality (i.e. survival of only the strongest and fastestgrowing individuals). Species successfully reared only at a $S_{\mathrm{m}} \geq 20 \%$ (survival $>80 \%$; Table 2 ) were categorised as stenohaline, while those which survived well at $S_{\mathrm{m}}<20 \%$ were classified as euryhaline, with the exception of the weakly euryhaline species Carcinus maenas (survival at $15 \%<80 \%$ ).

Handling of animals and larval rearing: Five sets of experiments with larvae in stage zoea I of 3 marine spe-

Table 1. List of species and their larval stages for which data on salinity-induced variations in biomass (dry mass, protein and lipid content) and osmoregulatory capacity (OC) are available. 'Range' denotes salinities used to study changes in larval biomass; 'optimal rearing conditions' include temperature and salinity; 'all larval stages' refers to all larval stages of each species (i.e. zoea I-III and megalopa for A. miersii; zoea I-IV and megalopa for A. roberti and A. ricordi)

\begin{tabular}{|c|c|c|c|c|c|}
\hline \multirow[t]{2}{*}{ Species and stage } & \multicolumn{2}{|c|}{ L Salinity } & \multirow[t]{2}{*}{ Variable } & \multirow{2}{*}{$\begin{array}{l}\text { Optimal rearing } \\
\text { conditions }\end{array}$} & \multirow[t]{2}{*}{ Source } \\
\hline & Tolerance & Range & & & \\
\hline $\begin{array}{l}\text { Hyas araneus } \\
\text { Zoea I }\end{array}$ & Stenohaline & $20-32$ & $\begin{array}{c}\text { OC } \\
\text { Biomass }\end{array}$ & $12^{\circ} \mathrm{C}, 32 \%$ & $\begin{array}{l}\text { Pfaff (1997) } \\
\text { Present study }\end{array}$ \\
\hline $\begin{array}{l}\text { Nephrops norvegicus } \\
\text { Zoea I }\end{array}$ & Stenohaline & $20-32$ & Biomass & $12^{\circ} \mathrm{C}, 32 \%$ & Present study \\
\hline $\begin{array}{l}\text { Liocarcinus pusillus } \\
\text { Zoea I }\end{array}$ & Stenohaline & $20-32$ & Biomass & $12^{\circ} \mathrm{C}, 32 \%$ & Present study \\
\hline $\begin{array}{l}\text { Homarus gammarus } \\
\text { Zoea I }\end{array}$ & Stenohaline & $20-32$ & Biomass & $18^{\circ} \mathrm{C}, 32 \%$ & Torres et al. (2002) \\
\hline $\begin{array}{l}\text { Cancer pagurus } \\
\text { Zoea I }\end{array}$ & Stenohaline & $20-32$ & Biomass & $18^{\circ} \mathrm{C}, 32 \%$ & Torres et al. (2002) \\
\hline $\begin{array}{l}\text { Carcinus maenas } \\
\text { Zoea I }\end{array}$ & $\begin{array}{l}\text { slightly } \\
\text { Euryhaline }\end{array}$ & $20-32$ & $\begin{array}{c}\text { OC } \\
\text { Biomass }\end{array}$ & $18^{\circ} \mathrm{C}, 32 \%$ & $\begin{array}{l}\text { Cieluch et al. (2004) } \\
\text { Torres et al. (2002) }\end{array}$ \\
\hline $\begin{array}{l}\text { Neohelice granulata } \\
\text { Zoea I }\end{array}$ & Euryhaline & $15-32$ & $\begin{array}{c}\text { OC } \\
\text { Biomass }\end{array}$ & $18^{\circ} \mathrm{C}, 32 \%$ & $\begin{array}{l}\text { Charmantier et al. (2002) } \\
\text { Torres et al. (2002) }\end{array}$ \\
\hline $\begin{array}{l}\text { Perisesarma fasciatum } \\
\text { Zoea I }\end{array}$ & Euryhaline & $10-32$ & Biomass & $24^{\circ} \mathrm{C}, 32 \%$ & Present study \\
\hline $\begin{array}{l}\text { Sesarma curacaoense } \\
\text { Zoea I }\end{array}$ & Euryhaline & $10-32$ & $\begin{array}{c}\text { OC } \\
\text { Biomass }\end{array}$ & $24^{\circ} \mathrm{C}, 25 \%$ & $\begin{array}{l}\text { Anger \& Charmantier (2000) } \\
\text { Present study }\end{array}$ \\
\hline $\begin{array}{l}\text { Armases miersii } \\
\text { All larval stages }\end{array}$ & Euryhaline & $5-32$ & $\begin{array}{c}\text { OC } \\
\text { Biomass }\end{array}$ & $24^{\circ} \mathrm{C}, 25 \%$ & $\begin{array}{l}\text { Charmantier et al. (1998) } \\
\text { Torres et al. (2007a) }\end{array}$ \\
\hline $\begin{array}{l}\text { Armases ricordi } \\
\text { All larval stages }\end{array}$ & Euryhaline & $15-32$ & $\begin{array}{c}\text { OC } \\
\text { Biomass }\end{array}$ & $24^{\circ} \mathrm{C}, 32 \%$ & $\begin{array}{l}\text { Anger et al. (2008b) } \\
\text { Torres et al. (2007a) }\end{array}$ \\
\hline $\begin{array}{l}\text { Armases roberti } \\
\text { All larval stages }\end{array}$ & Euryhaline & $10-32$ & $\begin{array}{c}\text { OC } \\
\text { Biomass }\end{array}$ & $24^{\circ} \mathrm{C}, 25 \%$ & $\begin{array}{l}\text { Anger et al. (2008b) } \\
\text { Torres et al. (2007a) }\end{array}$ \\
\hline
\end{tabular}


Table 2. Minimum salinity $\left(S_{\mathrm{m}}\right)$ used for biomass determinations, discriminated by species and larval instar. Sources as in Table 1. $\mathrm{Z}$ = zoea, $\mathrm{M}$ = megalopa, roman numbers refer to zoeal instars; 'all' refers to all larval stages

\begin{tabular}{|c|c|c|c|c|c|c|c|}
\hline \multicolumn{2}{|c|}{$5 \%$} & \multicolumn{2}{|l|}{$10 \%$. } & \multicolumn{2}{|c|}{$15 \%$} & \multirow{2}{*}{ 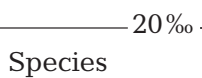 } & \multirow[b]{2}{*}{ Instar } \\
\hline Species & Instar & Species & Instar & Species & Instar & & \\
\hline \multirow{6}{*}{ A. miersii } & All (ZI-III, M) & A. roberti & $\mathrm{ZI}, \mathrm{M}$ & A. ricordi & All (ZI-IV, M) & C. maenas & ZI \\
\hline & & S. curacaoense & ZI & A. roberti & ZII-IV & H. gammarus & ZI \\
\hline & & P. fasciatum & ZI & N. granulata & ZI & C. pagurus & ZI \\
\hline & & & & & & H. araneus & ZI \\
\hline & & & & & & L. pusillus & ZI \\
\hline & & & & & & N. norvegicus & ZI \\
\hline
\end{tabular}

cies (Hyas araneus, Nephrops norvegicus, Liocarcinus pusillus) and 2 coastal/estuarine species (Perisesarma fasciatum, Sesarma curacaoense) were performed to obtain additional data on biomass (Table 1). The experiments were run following the methodology described in Torres et al. (2007a). Briefly, ovigerous females of each species were kept under optimal controlled conditions of photoperiod (12 h light:12 h dark cycle), temperature and salinity (see Table 1 for details), and fed with frozen isopods (Idotea sp.). Replicate groups of freshly hatched larvae were assigned to 3,4 or 5 salinity treatments according to the salinity tolerance of each species. Thus, test salinities varied among species as explained above (Table 1). Larvae were reared under the same conditions of photoperiod and temperature as those of ovigerous females. Zoeae were fed ad libitum on fresh Artemia sp. nauplii and transferred to clean water daily. Experimental salinities were obtained by mixing filtered seawater (32\%, Orion, pore size: $1 \mu \mathrm{m}$ ) with appropriate amounts of deionised tap water. Samples were taken for biochemical analyses shortly $(<24 \mathrm{~h})$ after hatching, and again at intermoult (at ca. $50 \%$ of the moulting cycle), thus completing a short exposure to the experimental salinities.

Dry mass, biochemical composition: To obtain 5 samples of each species, an appropriate number of larvae (representing $1 \mathrm{mg}$ dry mass [DW]) was gently rinsed in distilled water for $10 \mathrm{~s}$ and blotted on filter paper in order to eliminate salt residues. Subsequently, the larvae were transferred to $1.5 \mathrm{ml}$ vials and stored at $-80^{\circ} \mathrm{C}$. Samples were freeze-dried in a vacuum drier (Finn-Aqua Lyovac GT2E) for $48 \mathrm{~h}$ and DW was determined with a Sartorius MC1 RC 210 S balance (precision: $0.01 \mathrm{mg}$, capacity $210 \mathrm{~g}$ ). Afterwards, they were homogenized by sonication (Branson, Sonifier, Cell Disruptor B 15) with 5 strokes of $5 \mathrm{~s}$ on ice, and each homogenate was divided in 2 aliquots to perform lipid and protein content determinations respectively.

The protein content $(P)$ of the homogenate was determined using a modified method after Lowry et al. (1951) using the BioRad DC Protein Assay kit (Torres et al. 2007b). For this, $25 \mu \mathrm{l}$ of homogenate were mixed with $100 \mu \mathrm{l}$ of ice-cold $20 \%$ trichloroacetic acid (TCA) and incubated for $10 \mathrm{~min}$ at $4^{\circ} \mathrm{C}$. Then, the samples were centrifuged at $10000 \times g$ for $10 \mathrm{~min}$ at $4^{\circ} \mathrm{C}$ and the supernatant was discarded. The remaining pellet was dissolved in $300 \mu \mathrm{l} \mathrm{NaOH}(1 \mathrm{M}$ ) and incubated with shaking at $1400 \mathrm{rpm}$ for $30 \mathrm{~min}$ at $56^{\circ} \mathrm{C}$ in a Thermomixer Eppendorf. After incubation, 4 replicates of $30 \mu \mathrm{l}$ each of the dissolved sample were placed in a 96-well microplate and mixed with $20 \mu \mathrm{l}$ of Reagent A and $300 \mu \mathrm{l}$ of Reagent B (BioRad DC Protein Assay kit). The microplates were incubated for $15 \mathrm{~min}$ at room temperature in the absence of light and absorbance was determined (Thermoelectron Multiskan Spectrum spectrophotometer, wavelength: $750 \mathrm{~nm}$ ). To obtain the calibration curve, serial dilutions of bovine serum albumin (BSA, BioRad DC Protein Assay kit) were prepared.

The lipid content $(L)$ of the homogenate was determined by the sulphophosphovanillin method following Zöllner \& Kirsch (1962), modified for microplates (Torres et al. 2007a). Forty $\mu \mathrm{l}$ of homogenate were mixed with $300 \mu \mathrm{l}$ of ice-cold $\mathrm{CHCl}_{3} / \mathrm{CH}_{3} \mathrm{OH}$ (2:1). The samples were incubated for $15 \mathrm{~min}$ at room temperature and subsequently centrifuged at $10000 \times g$ for $20 \mathrm{~min}$ at $4^{\circ} \mathrm{C}$. Then $180 \mu \mathrm{l}$ of the lower phase were transferred to new tubes. These were left open to dry in a Thermomixer Eppendorf for 90 min at $56^{\circ} \mathrm{C}$ with shaking at $700 \mathrm{rpm}$. The dried pellet was dissolved in $200 \mathrm{\mu l}$ of concentrated $\mathrm{H}_{2} \mathrm{SO}_{4}$ and incubated for $10 \mathrm{~min}$ at $95^{\circ} \mathrm{C}$ with shaking at $1400 \mathrm{rpm}$ in a Thermomixer Eppendorf (tubes closed). The tubes were left cooling for $20 \mathrm{~min}$ at room temperature and 8 replicates of $20 \mu \mathrm{l}$ from each sample were distributed in two 96-well microplates. In the first plate (Blank: Plate 0), samples were mixed with $300 \mu \mathrm{l}$ of concentrated $\mathrm{H}_{3} \mathrm{PO}_{4}$, in the second (Plate 1), samples were mixed with $300 \mu$ of vanillin solution (8 $\mathrm{mM}$ conc. $\mathrm{H}_{3} \mathrm{PO}_{4}$ ). The microplates were incubated for colour development for $40 \mathrm{~min}$ at room temperature and subsequently measured (Thermoelectron Multiskan Spectrum spectrophotometer, wavelength: $530 \mathrm{~nm}$ ). The final values were obtained 
as the difference between Plate 1 and Plate 0 . The calibration curve was obtained by serial dilutions of a standard solution of cholesterol.

Range of tolerance to low salinity versus growth. The first hypothesis was tested following 2 approaches: (1) looking at the differences in larval growth at 2 fixed salinities, seawater (32\%) and a diluted medium (20 or $25 \%$ ); and (2) looking at differences in larval growth observed between seawater and the lower limit of salinity tolerance (20 to $5 \%$, depending on species and stage). For the first approach (1), we used moderately reduced salinities (20 and $25 \%$ ) to compare the responses of all species to exactly the same salinities. According to previous findings (Torres et al. 2002, 2007a), we expected that detrimental effects of low salinity on larval growth should decrease with an increasing range of tolerance (survival). For the second approach (2), we attempted to determine whether all species respond in the same way (presumably with reduced growth) at their lower limit of tolerance (survival $\geq 80 \%$ ), or if euryhaline species are able to maintain high growth rates even at their lower limit of tolerance.

(1) Growth at 2 fixed salinities: If growth is not affected by salinity, then the difference in biomass between larvae originating from the same population and growing at 2 salinity conditions for a fixed period should not be significant; otherwise, higher biomass should be achieved by larvae reared in seawater as compared to those in diluted seawater. The opposite difference (higher growth at a reduced salinity) is also theoretically possible, but has never been observed in our experiments. However, when different stages and species are compared, differences in growth may depend on variations in larval size (larger larvae can achieve higher increments in biomass than smaller larvae; Anger 2001), which would obscure the effect of salinity. In order to compare different species and stages, we developed an index of 'growth sensitivity' $\left(B_{\mathrm{H}-\mathrm{L}}^{\prime}\right)$ that measures the biomass-specific effect of salinity (Torres et al. 2007a) on growth:

$$
B_{\mathrm{H}-\mathrm{L}}^{\prime}=\left(B_{\mathrm{H}}-B_{\mathrm{L}}\right) \times 100 /\left[B_{\mathrm{H}} \times\left(S_{\mathrm{H}}-S_{\mathrm{L}}\right)\right]
$$

where $B_{\mathrm{H}}$ is biomass (DW, protein or lipid content per individual) measured at the end of the experiment at the higher salinity $\left(S_{\mathrm{H}}\right) ; B_{\mathrm{L}}$ is biomass at the lower salinity $\left(S_{\mathrm{L}}\right)$ in an interval $S_{\mathrm{H}}-S_{\mathrm{L}}$. This index removes potentially confounding effects of larval size, as differences in biomass between salinities $\left(B_{\mathrm{H}}-B_{\mathrm{L}}\right.$ in the numerator) are standardised to the biomass at the highest salinity ( $B_{\mathrm{H}}$ in the denominator). This index of biomassspecific effects of salinity can also be used to measure effects of salinity on growth rates achieved during an experimental period of time, as the average initial larval biomass at the beginning of the exposure period is the same for all salinity treatments (Torres et al. 2002, 2007a). The dimension of this index is a percentage of change in biomass per unit of biomass and salinity change. It should be noted that a higher index indicates stronger effects of low salinity. In addition, positive values indicate increments (increasing biomass) at the higher salinity, while negative values indicate decreasing biomass at that salinity (Torres et al. 2007a).

(2) Sensitivity to low salinity at the lower limit of tolerance: Effects of extremely low salinities on growth were expressed as biomass-specific effects of salinity, comparing growth at the minimum salinity allowing for $>80 \%$ survival $\left(S_{\mathrm{m}}\right)$ and the maximum salinity $\left(S_{\mathrm{H}}=\right.$ $32 \%$ ) in each set of experiments. Biomass-specific variation was therefore calculated using Eq. (1), but replacing $B_{\mathrm{L}}$ with $B_{\mathrm{m}}$ (biomass at the minimum salinity $S_{\mathrm{M}}$ ). Data of $B^{\prime}{ }_{32-\mathrm{m}}$ (calculated using biomass at 32 and at the minimum salinity) of each instar and species were then binned into categories defined by the respective salinity minimum. Statistical comparisons among these categories were made by 1-way ANOVA and Pearson's correlation (Zar 1996).

Osmoregulation versus growth. The relationship between osmoregulation and growth (second hypothesis) was evaluated by correlating the osmoregulatory capacity (OC) and the biomass-specific effect of salinity. OC is defined as the difference between the osmolalities of the hemolymph and the external medium (Charmantier 1998). Values of OC for different larval instars and species were taken from previous publications (see references in Table 1). The salinities at which the OC was determined $(5.3,10.3,17.0,26.7$ and $32.7 \%$ ) fall near $(\leq 2 \%)$ the values used for the evaluation of biomass-specific effects of salinity $(5.0,10.0,15.0,20.0,25.0$ and $32.0 \%$ o). The OC values for 15, 20 and 25\%o were estimated by linear interpolation. Given the proximity with the corresponding neighbouring values (e.g. 25 vs. 26.7), these estimates should not be affected by the type of interpolation. In other cases (e.g. 32 vs. 32.7), the difference between salinities used is less than $1 \%$ and therefore considered as irrelevant. Relationships between OC and growth sensitivity were evaluated by Pearson's correlation.

Statistical analyses. Data were analysed using 1-way ANOVA with salinity as the factor (Zar 1996). For all species, planned comparisons were made in order to test for significant growth from hatching to intermoult. The number of replicates was 4 to 5 for each species and salinity combination. Comparisons between different factors, after finding significant differences in the ANOVAs, were performed with the Student-NewmanKeuls test (SNK). The critical level $(\alpha)$ to reject the null hypothesis was 0.05. Prior to performing ANOVAs, normality (normal plots) and variance homogeneity (Cochran's $C$-test) were checked; none of these assumptions were violated. 


\section{RESULTS}

\section{Experiments}

Effects of salinity on early larval growth (measured as changes in DW, and $P$ and $L$ contents from hatching to the intermoult stage of zoea I larvae) varied among species. An exposure to low salinity caused a reduction in zoeal DW at intermoult in Sesarma curacaoense and Perisesarma fasciatum. In Hyas araneus and Nephrops norvegicus, larger increments in DW were found at higher salinities, and the larvae of Liocarcinus pusillus gained DW only at the highest salinity (32\%o; Fig.1, Table 3).

The protein content of the zoea I stage showed a significant increase from hatching to intermoult in all species and at all salinities, with the exception of Liocarcinus pusillus (increasing only at $32 \%$ ) and Perisesarma fasciatum (decreasing at all salinities except $25 \%$ ). Exposure to reduced salinities led to smaller increments of protein levels in the larvae of Nephrops norvegicus, L. pusillus, and P. fasciatum (Fig. 2, Table 3).
Table 3. Summary of 1-way ANOVA to evaluate the effect of salinity on dry mass, protein and lipid content of zoea I larvae of 5 decapod crustacean species. MSf, MSe: mean squares of factors and error, respectively; dff, dfe: degrees of freedom of factors and errors, respectively. Significant differences are in bold

\begin{tabular}{|lcccccc|}
\hline & dff & MSf & dfe & MSe & $F$ & $\mathrm{p}$ \\
\hline Dry mass & & & & & & \\
S. curacaoense & 2 & 117.74 & 12 & 9.86 & 11.9 & $<\mathbf{0 . 0 0 5}$ \\
P. fasciatum & 3 & 1.85 & 15 & 0.11 & 16.1 & $<\mathbf{0 . 0 0 0 1}$ \\
H. araneus & 2 & 445 & 12 & 17.20 & 25.9 & $<\mathbf{0 . 0 0 0 1}$ \\
N. norvegicus & 2 & 504781 & 40 & 3391 & 148.8 & $<\mathbf{0 . 0 0 0 1}$ \\
L. pusillus & 1 & 13.17 & 8 & 1.48 & 8.9 & $<\mathbf{0 . 0 2 5}$ \\
Protein & & & & & & \\
S. curacaoense & 2 & 2.81 & 12 & 0.80 & 3.5 & 0.064 \\
$P$. fasciatum & 3 & 0.03 & 15 & 0.001 & 27.6 & $<\mathbf{0 . 0 0 0 1}$ \\
H. araneus & 2 & 6.76 & 12 & 2.98 & 2.27 & 0.14 \\
N. norvegicus & 2 & 4070 & 40 & 374 & 10.9 & $<\mathbf{0 . 0 0 0 5}$ \\
L. pusillus & 1 & 0.89 & 8 & 0.10 & 8.7 & $<\mathbf{0 . 0 2 5}$ \\
Lipids & & & & & & \\
S. curacaoense & 2 & 0.73 & 12 & 0.15 & 4.9 & $<\mathbf{0 . 0 5}$ \\
P. fasciatum & 3 & 0.003 & 16 & 0.002 & 1.4 & 0.27 \\
H. araneus & 2 & 22.73 & 12 & 4.06 & 5.6 & $<\mathbf{0 . 0 2 5}$ \\
N. norvegicus & 2 & 2636 & 39 & 140 & 18.8 & $<\mathbf{0 . 0 0 0 1}$ \\
L. pusillus & 1 & 0.21 & 7 & 0.015 & 13.7 & $<\mathbf{0 . 0 1}$ \\
& & & & & & \\
\hline
\end{tabular}
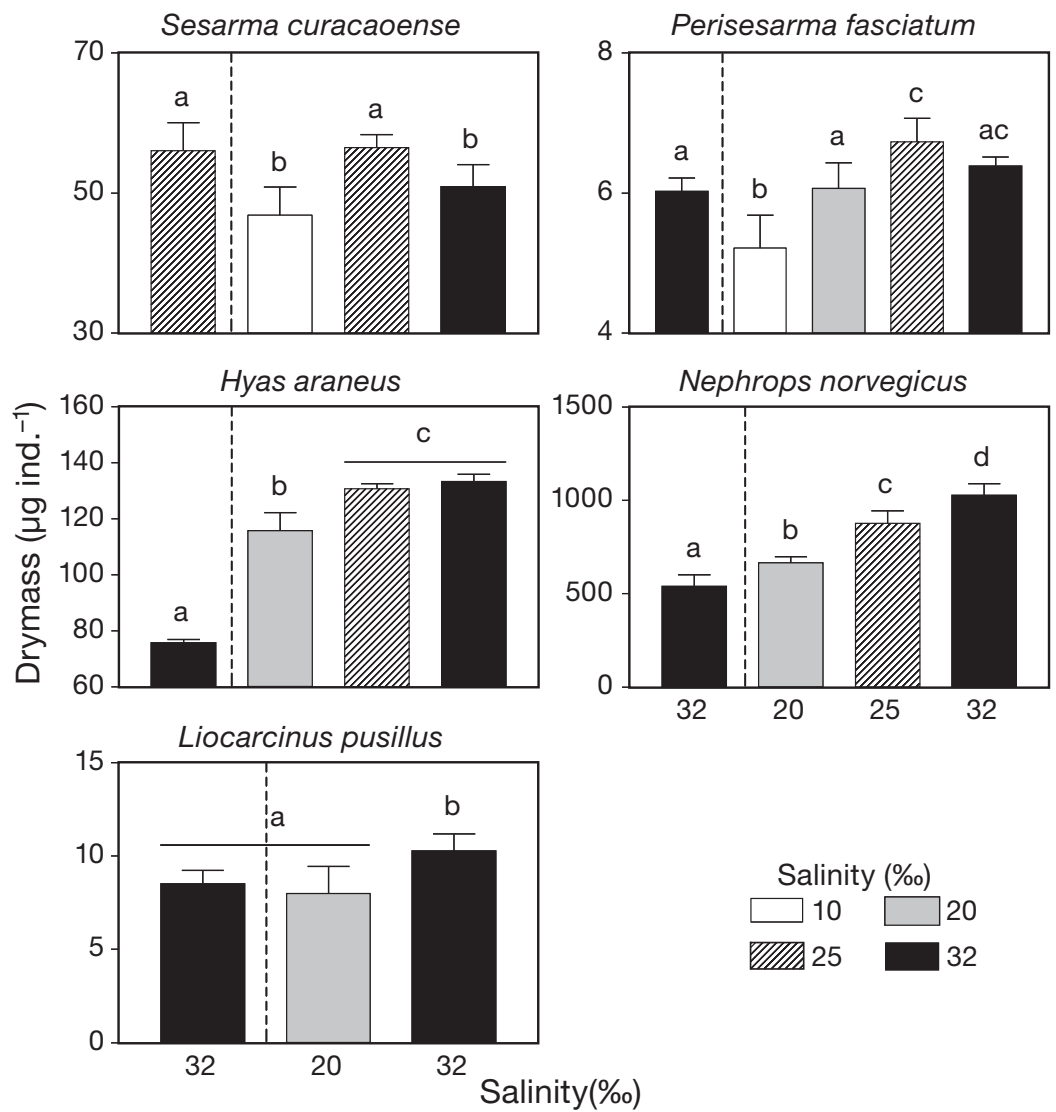

Fig. 1. Changes in dry mass (expressed as $\mu g$ ind.$^{-1}$ ) after exposure to test salinities (10 to $32 \%$ ). Left column: biomass at hatching; right columns: biomass at intermoult ( $50 \%$ of the zoea I moult cycle). Different letters denote significant differences after Student-Newman-Keuls (SNK) test among salinities at hatching and intermoult
The zoea I of Hyas araneus, Nephrops norvegicus and Liocarcinus pusillus showed significant increments in the lipid content at all salinities, while Sesarma curacaoense showed a lipid loss at $10 \%$, and the lipid content of Perisesarma fasciatum remained at a constant level. At intermoult, lower zoeal lipid contents were found in all species exposed to reduced salinities, except for $P$. fasciatum (Fig. 3, Table 3), where salinity had no significant effect.

\section{Range of tolerance to low salinity versus growth}

(1) Growth at 2 fixed salinities

The ranges of salinity 20 to $25 \%$ and 25 to $32 \%$ allowed for comparisons of biomass variations $\left(B_{25-20}^{\prime}\right.$ and $\left.B_{32-25}^{\prime}\right)$ using DW, $P$ and $L$ content from all tested species (Fig. 4, Table 4). Within the range 25 to $32 \%$, there was no significant effect of salinity on growth sensitivity, $B_{32-25}^{\prime}(\mathrm{r}<$ 0.41 , not significant for DW, $P$ and $L$ ): at $25 \%$, growth rates did not respond to salinity. Within the range 20 to $25 \%$, there was a significant correlation between the range of tolerance and growth sensitivity, $B_{25-20}^{\prime}$ (Fig. 4). Growth was 

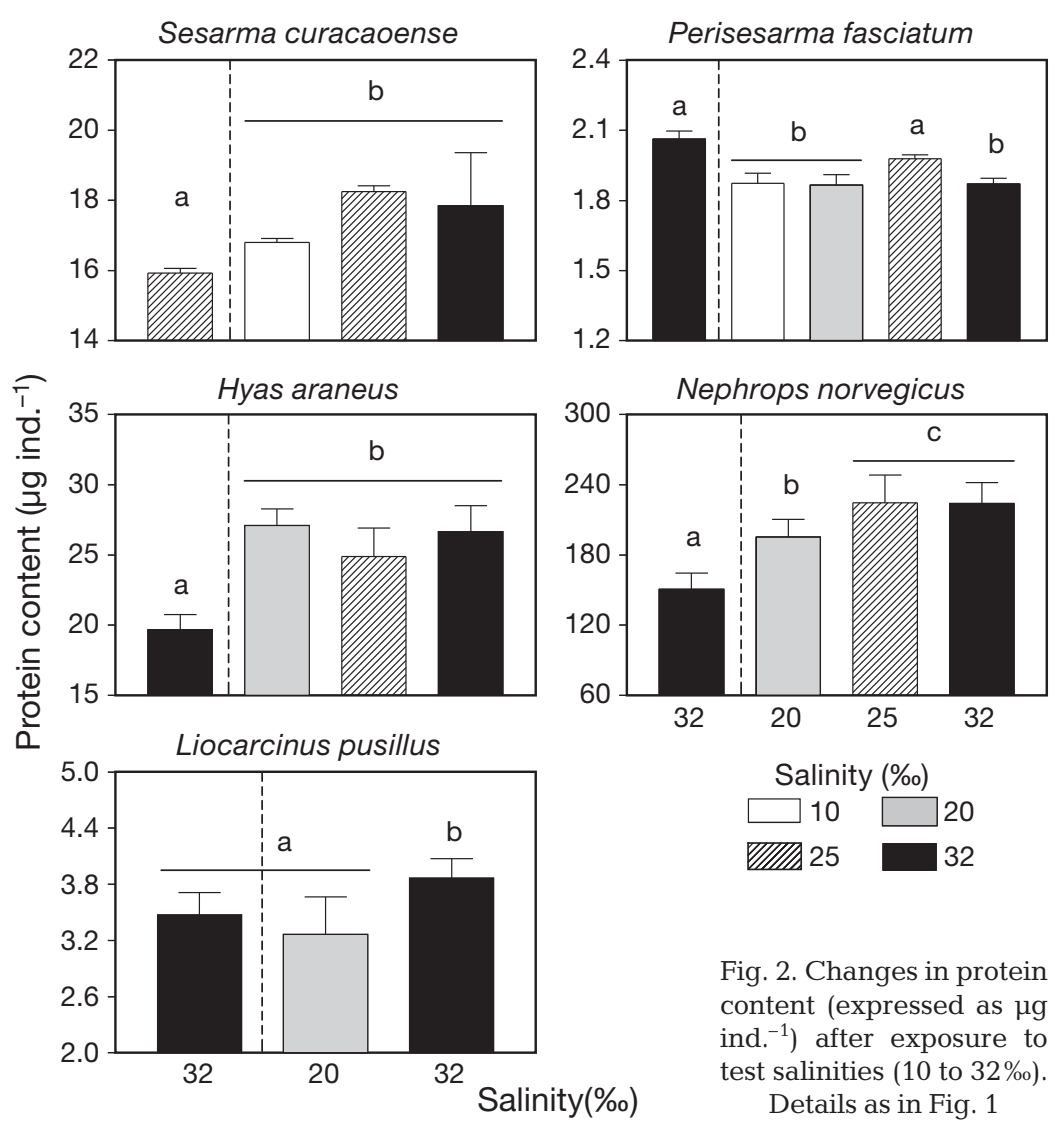

Fig. 2. Changes in protein content (expressed as $\mu \mathrm{g}$ ind. $^{-1}$ ) after exposure to test salinities (10 to $32 \%$ ). Details as in Fig. 1
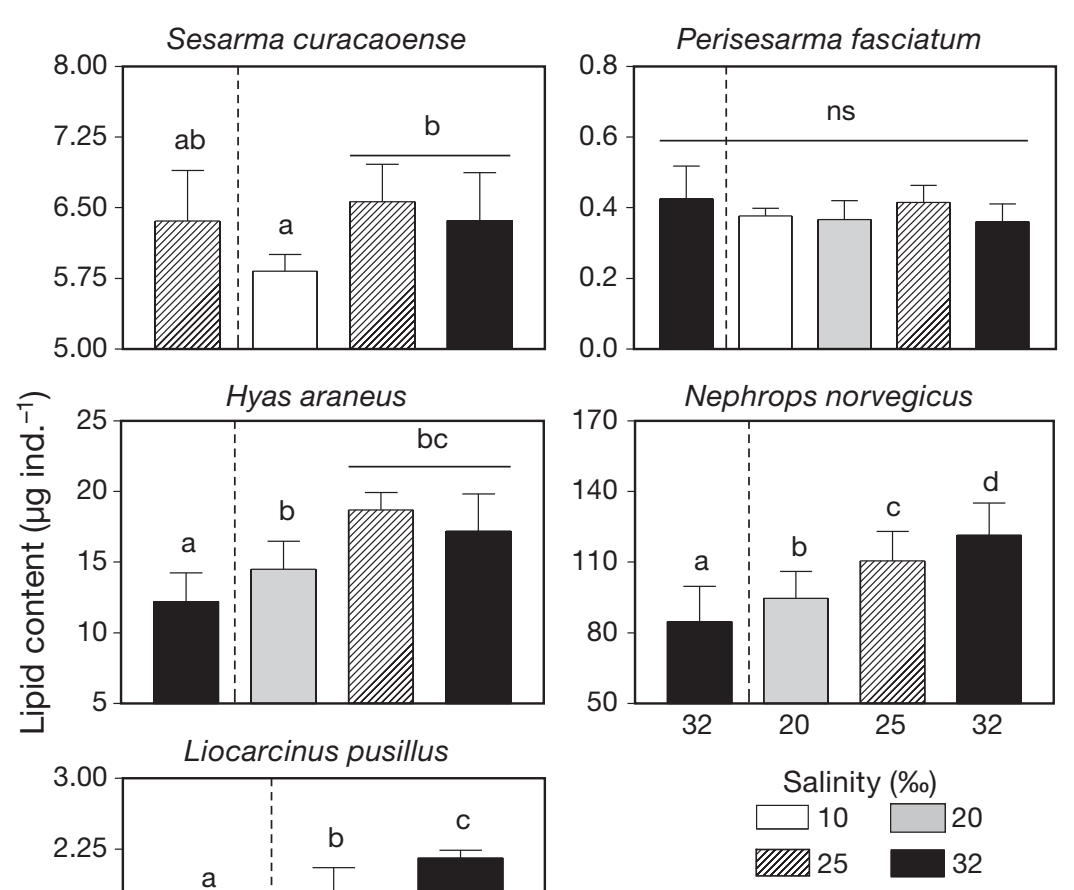

Fig. 3. Changes in lipid content (expressed as $\mu \mathrm{g}$ ind. ${ }^{-1}$ ) after exposure to test salinities (10 to $32 \%$ ). Details as in Fig. 1, ns: no significant difference less affected in species and stages with wider ranges of salinity tolerance than in those with narrower ranges after exposure to moderately low salinity (20\%). In general, stenohaline species (minimum salinity tolerated, $S_{\mathrm{m}} \geq 20 \%$ ) showed high positive values of $B_{25-20}^{\prime}$ (e.g. Cancer pagurus zoea I, $B^{\prime}$ values are as follows: $\mathrm{DW}=5.3$, $\mathrm{P}=6.9, \mathrm{~L}=4.5$ ), showing strong detrimental effects of low salinity on growth. By contrast, euryhaline species $\left(S_{\mathrm{m}}<20 \%\right)$ had low positive and/or negative values (e.g. Armases miersii zoea $\mathrm{I}=B_{25-20}^{\prime} \mathrm{DW}=1.3$, $P=-0.6, L=0.7$ ) indicating that the negative effects of low salinity on growth were generally weaker (Fig. 4, Table 4).

(2) Sensitivity to low salinity at the lower limit of tolerance

There was a significant correlation between the range of tolerance and growth sensitivity (Fig. 5). Species with a lower value of minimum salinity tolerance $\left(S_{\mathrm{m}}\right)$ also showed lower $B^{\prime}{ }_{32-\mathrm{m}}$ values (Fig. 5). Therefore, even at the lowest tolerance limit, euryhaline species tend to perform better than stenohaline species. In addition, there was a considerable variation in $B_{32-\mathrm{m}}^{\prime}$ values at the highest $S_{\mathrm{m}}$ value (when salinity was $20 \%$ ). For $P$ and $L$ contents, the zoea I of Homarus gammarus and Cancer pagurus showed the highest $B_{32-\mathrm{m}}^{\prime}$ values and Hyas araneus the lowest. Regressions between the range of tolerance and growth sensitivity, restricted to zoea I were not significant, because the number of data points was not sufficient. However, comparisons ( $t$ tests) of extremely stenohaline $\left(S_{\mathrm{m}}=20 \%\right.$ o) versus euryhaline species $\left(S_{\mathrm{m}}<20 \%\right.$ o showed significant values for DW ( $p<$ 0.02 ), i.e. lower growth at low salinities. For protein and lipid contents, differences were marginally not significant $(P$ : $t=2.56, \mathrm{p}=0.054 ; L: F_{3,8}=3.71, \mathrm{p}=$ $0.061)$.

\section{Osmoregulatory capacity versus growth}

The relationship between OC and effects of salinity on biomass was evaluated using the biomass variation in the 20 

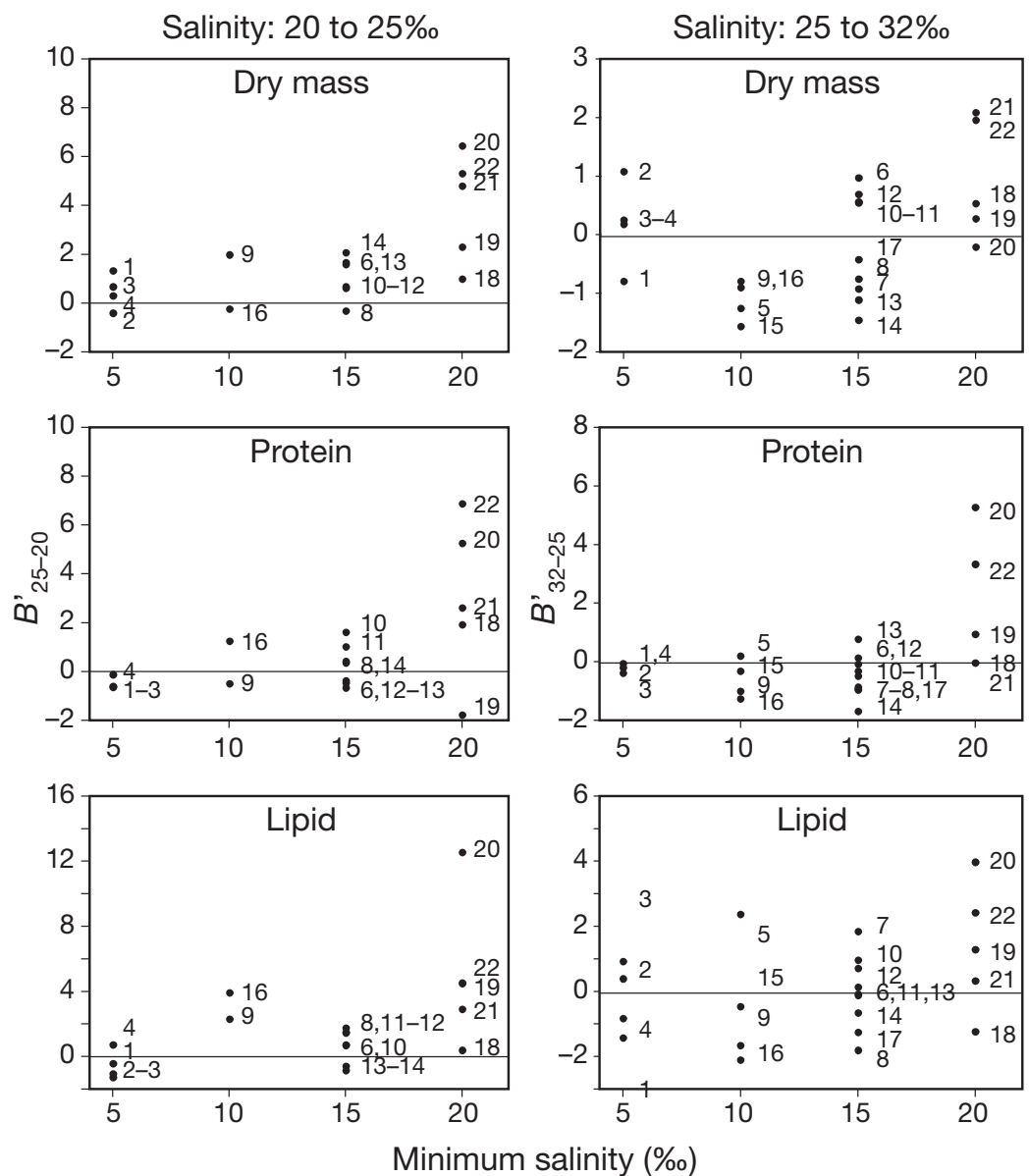

Fig. 4. Patterns of biomass $(B)$-specific effects of salinity within 2 different salinity ranges (20 to $25 \%$, 25 to $32 \%$ ) $\left(B_{25-20}^{\prime}, B_{32-25}^{\prime}\right)$ in larval instars of 11 species of decapod crustaceans. Numbers refer to species - 1 to 4 : Armases miersii (zoea I to III, megalopa); 5 to 9: Armases roberti (zoea I to IV, megalopa); 10 to 14: Armases ricordi (zoea I to IV, megalopa); 15: Sesarma curacaoense (zoea I); 16: Perisesarma fasciatum (zoea I); 17: Neohelice granulata (zoea I); 18: Carcinus maenas (zoea I); 19: Hyas araneus (zoea I); 20: Homarus gammarus (zoea I); 21: Nephrops norvegicus (zoea I); 22: Cancer pagurus (zoea I). Strong euryhaline species are identified with numbers below 18, weak euryhaline species with number 18, stenohaline species with numbers above 18. Correlations between $B_{32-25}^{\prime}$ and minimum salinity were not significant and are not included in the graphs

Table 4. Values of $B^{\prime}{ }_{32-25}$ in euryhaline species not plotted in Fig. 4 (see also for definitions), as no data on $B^{\prime}{ }_{25-20}$ were available

\begin{tabular}{|lcrr|}
\hline Species & Dry mass & Protein & Lipids \\
\hline Sesarma curacaoense (Zoea I) & -1.56 & -0.32 & -0.46 \\
Neohelice granulata (Zoea I) & -0.42 & -0.94 & -1.24 \\
Armases roberti (Zoea I) & -1.25 & 0.20 & 2.37 \\
Armases roberti (Zoea III) & -0.92 & -0.94 & 1.85 \\
\hline
\end{tabular}

to $32 \%$ range, with $\mathrm{OC}$ at $20 \%\left(\mathrm{OC}_{20}\right)$, and maximal $\mathrm{OC}\left(\mathrm{OC}_{\mathrm{M}}\right)$ reached by each instar. We used this salinity range to facilitate inclusion of data from both stenohaline and euryhaline species in our analyses.
Overall, there was a significant negative correlation between $\mathrm{OC}_{20}$ and $B_{32-20}$ and between $\mathrm{OC}_{\mathrm{M}}$ and $B^{\prime}{ }_{32-20}$ (Fig. 6). Weaker detrimental effects of salinity on larval growth are thus correlated with an increase in the OC. The only exception was found in $B^{\prime}{ }_{32-20}$ for proteins, where the correlation was marginally not significant, probably due to an excessively low $B^{\prime}{ }_{32-20}$ value of Hyas araneus (see Fig. 6, dot within circle).

\section{DISCUSSION}

There is a paucity of comparative data available that allow for generalisations on the effects of salinity variation on the growth of larval decapods (Anger 2001, 2003). Here we present a data set that includes the effect of salinity on short-term larval growth (measured in terms of changes in biomass) for different species and larval instars varying in their range of salinity tolerance (estimated from survival data) and osmoregulatory capacity (data taken from previous studies). We found the following patterns: (1) biomass growth in instars with a wide range of salinity tolerance (defined by survival $>80 \%$ ) was consistently less sensitive to reduced salinity than that in instars with a narrower range of tolerance; and (2) with higher osmoregulatory capacity, the biomass-specific effect of low salinity on biomass accumulation was lower.

The low sensitivity of larval growth to changes in salinity exhibited by species with a wide range of salinity tolerance (high survival at 5 to $32 \%$ ) appears to be based on their ability to osmoregulate, which thus may be considered as an adaptation to life in habitats characterised by low and/or highly variable salinities (Torres et al. 2002, $2007 \mathrm{a}$ ). The ability to osmoregulate ensures that metabolic and developmental processes take place with high efficiency under variable environmental conditions. In adult stages of brachyuran crustaceans, osmoregulatory capacity is positively correlated with the activity of $\mathrm{Na}^{+}-\mathrm{K}^{+}$-ATPase (Lucu \& Towle 2003), and this is true also for larval stages (Cieluch et al. $2004,2007)$. High $\mathrm{Na}^{+}-\mathrm{K}^{+}$-ATPase activity in the posterior gills of crabs is largely explained by higher mRNA expression of the $\mathrm{Na}^{+}-\mathrm{K}^{+}$-ATPase $\alpha$-subunit in poste- 

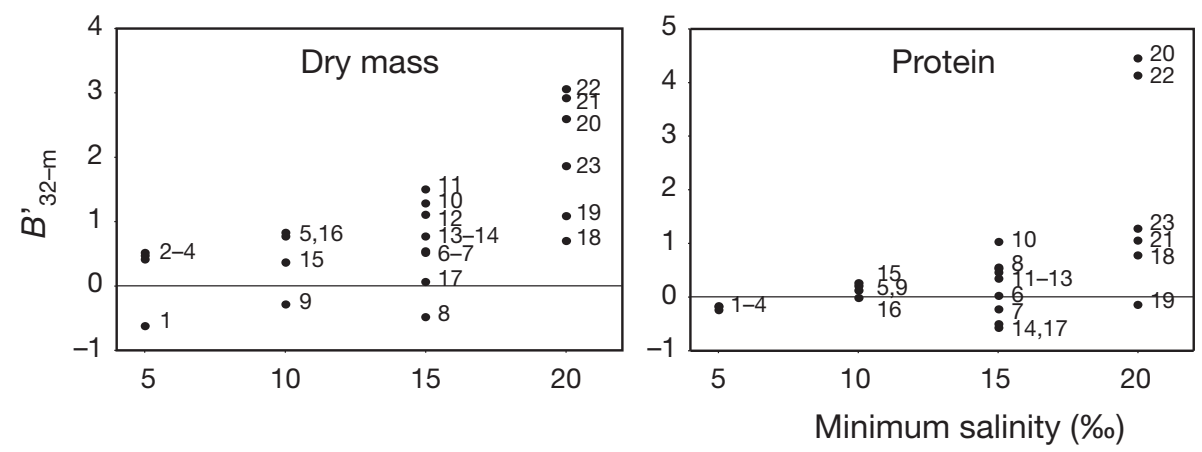

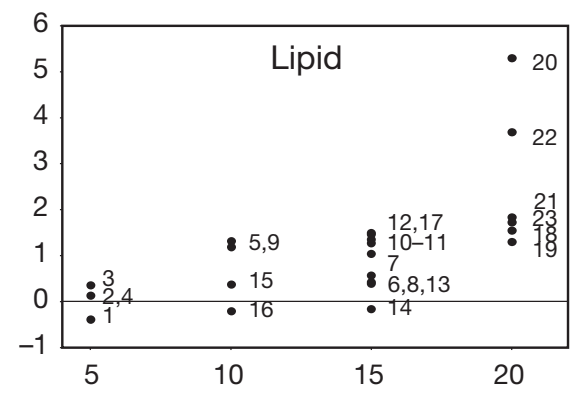

Fig. 5. Relationship between minimal salinity $\left(S_{\mathrm{m}}\right)$ for biomass determination (set to ensure larval survival $>80 \%$ ) and biomassspecific effects of salinity in larval instars of 12 species of decapod crustaceans. Species and definitions as in Fig. $4 ;$ number 23 refers to Liocarcinus pusillus (zoea I)
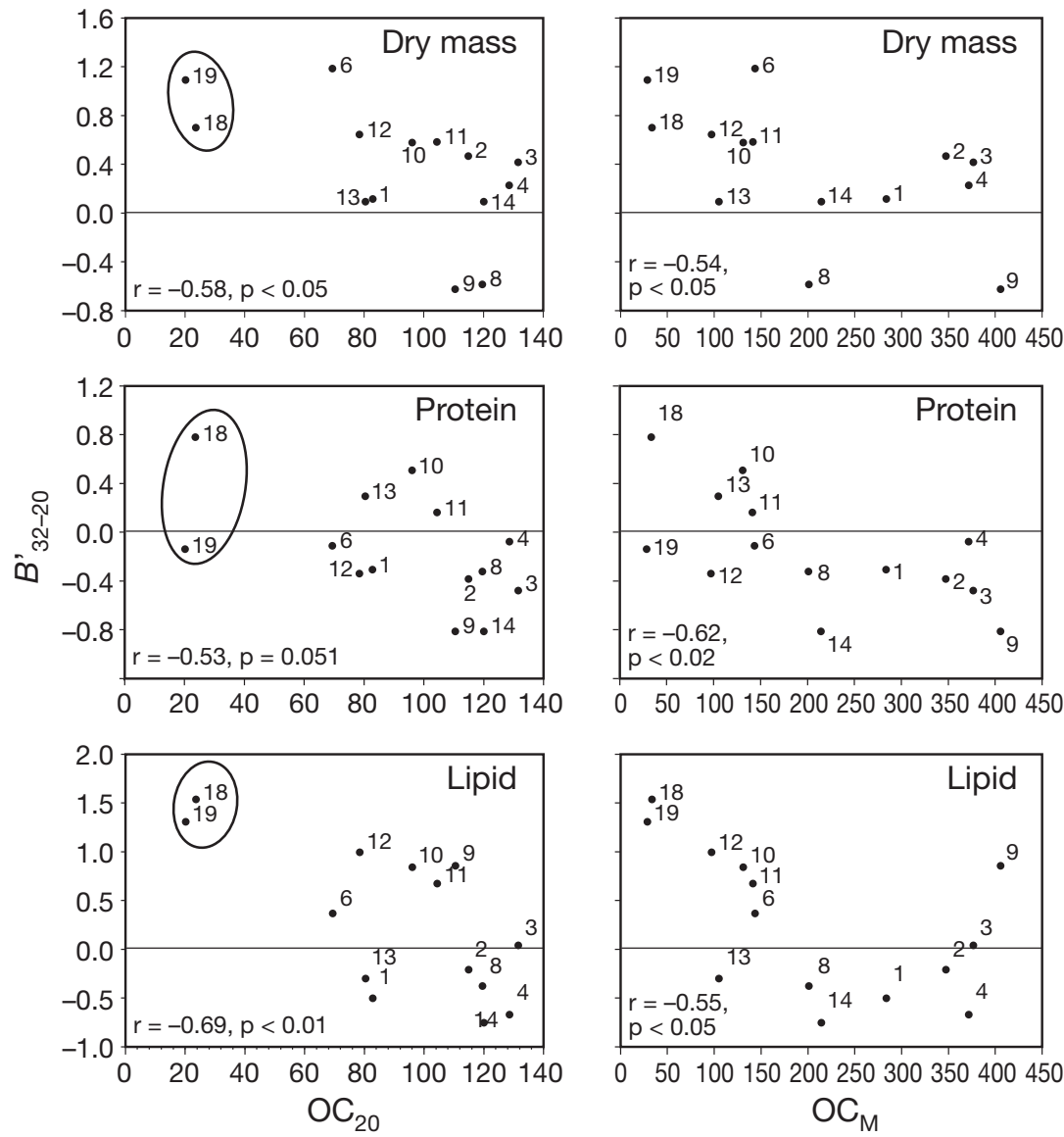

$0 \quad 50100150200250300350400450$ $\mathrm{OC}_{\mathrm{M}}$

Fig. 6. Relationship between osmoregulatory capacity at $20 \%\left(\mathrm{OC}_{20}\right)$ and at the minimum salinity tested $\left(\mathrm{OC}_{\mathrm{M}}\right)$ and biomass-specific effects of salinity $\left(B^{\prime}{ }_{32-20}\right)$, in larval instars of 6 species of decapod crustaceans. Species and definitions as in Fig. 4

rior gills (Towle et al. 2001, Luquet et al. 2005). In the larval stages of the crab Armases miersii (a strong osmoregulator), de novo synthesis of $\mathrm{Na}^{+}-\mathrm{K}^{+}$-ATPase has been observed as a response to reduced salinities (G. Torres, unpubl. data).

In osmoregulating stages, the energetic costs for osmoregulation do not appear to significantly impair early larval growth, allowing sustained growth. By contrast, in larval instars with low osmoregulatory capacity, exposure to low salinity led to strongly reduced growth or even biomass losses. Low internal osmolality may significantly affect several metabolic processes in osmoconformers. While reduced dry mass at low salinities may reflect effects on both inorganic and organic constituents of biomass (Anger 2003), the protein and lipid fractions reflect negative effects on feeding and/or assimilation, or increased costs for maintenance and developmental processes. For instance, zoeal stages of the stenohaline crab Cancer irroratus (Charmantier \& Charmantier-Daures 1991), exposed to low salinities, showed reduced feeding and respiration rates, reduced energy content and increased nitrogen excretion rates (Johns 1982). Similarly, the zoea I of Carcinus maenas, exposed to $15 \%$, showed low respiration rates, and reduced carbon and nitrogen contents (Anger et al. 1998). In the relatively stenohaline larvae of these species, low salinity caused a decrease in the efficiencies of assimilation and conversion of food into tissues (Anger 2003).

In species with a narrow range of salinity tolerance (20 to $32 \%$ ) we found 2 patterns: (1) a reduction of both proteins and lipids leading to rather constant $L: P$ ratios: Liocarcinus pusillus (0.52 to 0.56), Cancer pagurus (0.10 to 0.11), and Nephrops norvegicus (0.48 to 0.54); and (2) a reduction of lipids but not of proteins, leading to reduced $L: P$ ratios at low salinity: Hyas araneus (0.54 to 0.65). The lobster Homarus gammarus may fall in an intermedi- 
ate category: although the L:P ratios (0.19 to 0.30$)$ varied with salinity, as in Hyas araneus, there were significant losses of both protein and lipid. In the first group, low salinity is likely to have led to both lower assimilation and conversion efficiencies, which became conspicuous as a negative growth between postmoult and intermoult. However, the unaffected protein content in Hyas araneus suggests that low salinity affected the storage of lipid reserves rather than feeding or assimilation. Differences in how salinity may affect metabolism must explain the high interspecific variability in effects of salinity on larval growth, and ultimately, survival. These differences may be associated with small differences in the tolerance of low salinities: while the zoeal development of C. pagurus cannot be completed at $20 \%$ (G. Torres unpubl. data), this is possible for Hyas araneus, which also occurs in the brackish western Baltic Sea (Anger 1985). Some limited capacity for osmoregulation within the 20 to $32 \%$ range, is suggested by the $\mathrm{OC}_{20}$ of the zoea I of Hyas araneus, which is as high as that of the weakly hyper-osmoregulating zoea I of C. maenas (Fig. 6, encircled dots). Unfortunately, no OC data are available for other stenohaline species such as C. pagurus or Homarus gammarus. The OC existing data for Homarus gammarus (Charmantier et al. 2001) were obtained from a different population, which is probably more tolerant to low salinities than the one used here for biomass determinations; therefore, we did not use these different data sets for comparisons.

If osmoregulation gives such an advantage to crustacean larvae, then why do osmoconforming species exist? The capacity to osmoregulate may be considered as a complex plastic trait based on a set of tissue, cellular and molecular responses to changes in internal osmolality. Therefore, osmoregulation may be energetically too expensive under marine conditions (i.e. salinity varying in the 32 to $35 \%$ range), where osmoregulation is not needed, i.e. osmoregulation is a 'waste of energy' or a 'luxury' that is negatively selected by physically stable marine environments. This also may explain the ontogenetic pattern of osmoregulation in the crab Neohelice granulata (Charmantier et al. 2002): the first zoeal stage, which is released in estuarine and sometimes even oligohaline waters, is a hyper-osmoregulator in dilute media, but this capacity is lost in the subsequent stages, which presumably develop outside the estuaries and may not need to hyper-regulate (Anger et al. 2008a). The capacity to hyper-osmoregulate is later recovered in the last larval stage, the megalopa, which re-invades estuarine habitats to recruit to the adult populations (Luppi et al. 2002). Similar relationships between larval capabilities of osmoregulation and patterns of larval dispersal were also found in Armases roberti, a crab that releases its larvae in waters with very low salinity (Anger et al. 2008b). It thus appears that it is advantageous to decrease and/or suppress the structures and functions that are responsible for osmoregulation in ontogenetic stages or species where this capability is not needed. As in any other plastic trait, costs of osmoregulation, may be related to the energy required to maintain the necessary structures or genetic costs (DeWitt et al. 1998, Auld et al. 2010). Whatever the ultimate cause is, we still do not know the actual costs of osmoregulation in crustacean larvae and we still need to understand how osmoregulatory structures change through development in species with the ontogenetic patterns shown by N. granulata and $A$. roberti.

In euryhaline brachyuran crab species, the larvae are likely exposed to hypo-osmotic stress; thus larval capabilities of hyper-osmoregulation provide a considerable advantage. Besides reducing mortality, their growth rates are little affected by low salinities. The indirect effects of osmotic stress, such as delayed moulting and the consequent increase in pelagic predator-induced mortality should remain low in osmoregulating larval stages developing in estuarine habitats. High growth rates suggest that these larvae maintain high rates of feeding or assimilation, allowing for an optimal use of the comparatively high levels of food available in estuarine waters (Morgan 1992, 1995).

Acknowledgements. We thank U. Nettelmann for help in the rearing of larvae and crabs and A. Johnson for his comments and suggestions to improve the manuscript. G.T. was financially supported by the Deutscher Akademischer Austauschdienst (DAAD, Bonn, Germany) funding this study as a part of her doctoral dissertation and L.G. by the Alexander-vonHumboldt Foundation (Bonn, Germany) with a postdoctoral research grant. The experiments comply with the current animal manipulation laws in Germany.

\section{LITERATURE CITED}

Anger K (1985). Influence of salinity on larval development of the spider crab, Hyas araneus, reared in the laboratory. In: Gray JS, Christiansen ME (eds) Marine biology of polar regions and effects of stress on marine organisms. Wiley, Chichester, p. 463-474

Anger K (1995) Developmental biology of Armases miersii (Grapsidae), a crab breeding in supratidal rock pools. I. Facultative lecithotrophy of larval stages. Mar Ecol Prog Ser 117:75-81

Anger K (2001). The biology of decapod crustacean larvae. Crustacean issues, Vol 14. AA Balkema, Lisse, The Netherlands

Anger K (2003) Salinity as a key parameter in the larval biology of decapod crustaceans. Invertebr Reprod Dev 43: $29-45$

> Anger K, Charmantier G (2000) Ontogeny of osmoregulation and salinity tolerance in a mangrove crab, Sesarma curacaoense (Decapoda: Grapsidae). J Exp Mar Biol Ecol 251: $265-274$ 
Anger K, Spivak E, Luppi T (1998) Effects of reduced salinities on development and bioenergetics of early larval shore crab, Carcinus maenas. J Exp Mar Biol Ecol 220: 287-304

- Anger K, Torres G, Giménez L (2006) Metamorphosis of a sesarmid river crab, Armases roberti: stimulation by adult odours versus inhibition by salinity stress. Mar Freshwat Behav Physiol 39:269-278

Anger K, Spivak E, Luppi T, Bas C, Ismael D (2008a) Larval salinity tolerance of the South American salt-marsh crab, Neohelice (Chasmagnathus) granulata: physiological constraints to estuarine retention, export and reimmigration. Helgol Mar Res 62:93-102

Anger K, Torres G, Charmantier-Daures M, Charmantier G (2008b) Adaptive diversity in congeneric coastal crabs: ontogenetic patterns of osmoregulation match life-history strategies in Armases spp. (Decapoda, Sesarmidae). J Exp Mar Biol Ecol 367:28-36

Augusto A, Silva PA, Greene LJ, Laure HJ, McNamara JC (2009) Evolutionary transition to freshwater by ancestral marine palaemonids: evidence from osmoregulation in a tide pool shrimp. Aquat Biol 7:113-122

Auld JR, Agrawal AA, Relyea RA (2010) Re-evaluating the costs and limits of adaptive phenotypic plasticity. Proc $\mathrm{R}$ Soc B 277:503-511

> Charmantier G (1998) Ontogeny of osmoregulation in crustaceans: a review. Invertebr Reprod Dev 33:177-190

> Charmantier G, Charmantier-Daures M (1991) Ontogeny of osmoregulation and salinity tolerance in Cancer irroratus; elements of comparison with C. borealis (Crustacea, Decapoda). Biol Bull 180:125-134

Charmantier G, Charmantier-Daures M, Anger K (1998) Ontogeny of osmoregulation in the grapsid crab Armases miersii (Crustacea, Decapoda). Mar Ecol Prog Ser 164: 285-292

> Charmantier G, Haond C, Lignot JH, Charmantier-Daures M (2001) Ecophysiological adaptation to salinity throughout a life cycle: a review in homarid lobsters. J Exp Biol 204: 967-977

> Charmantier G, Giménez L, Charmantier-Daures M, Anger K (2002) Ontogeny of osmoregulation, physiological plasticity, and export strategy in the grapsid crab Chasmagnathus granulata (Crustacea, Decapoda). Mar Ecol Prog Ser 229:185-194

Charmantier G, Charmantier-Daures M, Towle D (2009). Osmotic and ionic regulation in aquatic arthropods. In: Evans DH (ed) Osmotic and ionic regulation: cells and animals. CRC Press, Boca Raton, FL

Chen Y, Shaw P, Wolcott T (1997) Enhancing estuarine retention of planktonic larvae by tidal currents. Estuar Coast Shelf Sci 45:525-533

> Cieluch U, Anger K, Aujoulat F, Buchholz F, CharmantierDaures M, Charmantier G (2004) Ontogeny of osmoregulatory structures and functions in the green crab, Carcinus maenas (Crustacea, Decapoda). J Exp Biol 207:325-336

Cieluch U, Anger K, Charmantier-Daures M, Charmantier G (2007) Salinity tolerąnce, osmoregulation, and immunolocalization of $\mathrm{Na}-\mathrm{K}$-ATPase in larval and early juvenile stages of the Chinese mitten crab, Eriocheir sinensis (Decapoda, Grapsoidea). Mar Ecol Prog Ser 329:169-178

DeWitt TJ, Sih A, Wilson DS (1998) Costs and limits of phenotypic plasticity. Trends Ecol Evol 13:77-81

Freire CA, Cavassin F, Rodrigues EN, Torres AH, McNamara JC (2003) Adaptive patterns of osmotic and ionic regulation, and the invasion of fresh water by the palaemonid shrimps. Comp Biochem Physiol A 136:771-778
Giménez L, Anger K (2005) Effects of temporary food limitation on survival and development of brachyuran crab larvae. J Plankton Res 27:485-494

> Johns DM (1982) Physiological studies on Cancer irroratus larvae. III. Effects of temperature and salinity on the partitioning of energy resources during development. Mar Ecol Prog Ser 8:75-85

Jury SH, Kinnison MT, Howell WH, Watson WH (1994) The effects of reduced salinity on lobster (Homarus americanus Milne Edwards) metabolism: implications for estuarine populations. J Exp Mar Biol Ecol 176:167-185

Kinne O (ed) (1971) Salinity. In: Marine ecology, Vol 1, Environmental factors Part 2. Wiley-Interscience, London, p 683-1083

Lowry OH, Rosebrough NJ, Farr AL, Randall RJ (1951) Protein measurement with the Folin phenol reagent. J Biol Chem 193:265-275

Lucu C, Towle D (2003) $\mathrm{Na}^{+}-\mathrm{K}^{+}$-ATPase in gills of aquatic crustacean. Comp Biochem Physiol A 135:195-214

Luppi TA, Spivak ED, Anger K, Valero JL (2002) Patterns and processes of Chasmagnathus granulata and Cyrtograpsus angulatus (Brachyura: Grapsidae) recruitment in Mar Chiquita coastal Lagoon, Argentina. Estuar Coast Shelf Sci 55:287-297

Luquet CM, Weihrauch D, Senek M, Towle DW (2005) Induction of branchial ion transporter mRNA expression during acclimation to salinity change in the euryhaline crab Chasmagnathus granulatus. J Exp Biol 208:3627-3636

> Morgan SG (1992) Predation by planktonic and benthic invertebrates on larvae of estuarine crabs. J Exp Mar Biol Ecol 163:91-110

Morgan SG (1995) Life and death in the plankton: larval mortality and adaptation. McEdward LR (ed) Ecology of marine invertebrate larvae. CRC Press, Boca Raton, p 279-321

> Ogburn MB, Jackson JL, Forward RB (2007) Comparison of low salinity tolerance in Callinectes sapidus Rathbun and Callinectes similis Williams postlarvae upon entry into an estuary. J Exp Mar Biol Ecol 352:343-350

> Paula J (1998) Larval retention and dynamics of the prawns Palaemon longirostris $\mathrm{H}$ Milne Edwards and Crangon crangon Linnaeus (Decapoda, Caridea) in the Mira estuary, Portugal. Invertebr Reprod Dev 33:221-228

> Péqueux A (1995) Osmotic regulation in crustaceans. J Crustac Biol 15:1-60

Pfaff K (1997). Einfluß der Salinität auf den Stoffbestand der Larvenstadien einer marinen Dekapodenart. MSc thesis, University of Darmstadt

Queiroga H, Blanton J (2004) Interactions between behaviour and physical forcing in the control of horizontal transport of decapod crustacean larvae. Adv Mar Biol 47: $107-214$

Rainbow PS, Black WH (2001) Effects of changes in salinity on the apparent water permeability of three crab species: Carcinus maenas, Eriocheir sinensis and Necora puber. J Exp Mar Biol Ecol 264:1-13

Richmond C, Woodin S (1996) Short-term fluctuations in salinity: effects on planktonic invertebrate larvae. Mar Ecol Prog Ser 133:167-177

Strathmann RR (1982) Selection for retention or export of larvae in estuaries. In: Kennedy VS (ed) Estuarine comparisons. Academic Press, San Diego, CA, p 521-536

> Tankersley RA, Bullock TM, Forward RB, Rittschof D (2002) Larval release behaviors in the blue crab Callinectes sapidus: role of chemical cues. J Exp Mar Biol Ecol 273:1-14

> Torres G, Giménez L, Anger K (2002) Effects of reduced salinity on the biochemical composition (lipid, protein) of zoea 
1 decapod crustacean larvae. J Exp Mar Biol Ecol 277: $43-60$

Torres G, Anger K, Giménez L (2006) Effects of reduced salinities on metamorphosis of a freshwater-tolerant sesarmid crab, Armases roberti: is upstream migration in the megalopa stage constrained by increasing osmotic stress? J Exp Mar Biol Ecol 338:134-139

Torres G, Giménez L, Anger K (2007a) Effects of reduced salinities on larval growth and proximate biochemical composition are related to life-histories: the genus Armases as a model. Comp Biochem Physiol B 148:209-224

Torres G, Charmantier-Daures M, Chifflet S, Anger K (2007b) Effects of long-term exposure to different salinities on the location and activity of $\mathrm{Na}^{+}-\mathrm{K}^{+}$-ATPase in the gills of juve-

Editorial responsibility: Hans Heinrich Janssen, Oldendorf/Luhe, Germany nile mitten crab, Eriocheir sinensis. Comp Biochem Physiol A 147:460-465

Towle DW, Paulsen RS, Weihrauch D, Kordylewski M, Salvador C, Lignot JH, Spanings-Pierrot C (2001) $\mathrm{Na}^{+}-\mathrm{K}^{+}$ATPase in gills of the blue crab Callinectes sapidus: cDNA sequencing and salinity-related expression of alphasubunit mRNA and protein. J Exp Biol 204:4005-4012

Zar J (1996). Biostatistical analysis. Prentice Hall, Upper Saddle River, NJ

Zöllner N, Kirsch K (1962) Über die quantitative Bestimmung von Lipoiden (Mikromethode) mittels der vielen natürlichen Lipoiden (allen bekannten Plasmalipoide) gemeinsamen Sulfophosphovanillin-Reaction. Z Gesamte Exp Med 135:545-561

Submitted: November 3, 2010; Accepted: March 23, 2011 Proofs received from author(s): May 25, 2011 